\title{
Collaborative Design of Parametric Sustainable
}

\section{Architecture}

\author{
Ir. J. C. (Hans) Hubers \\ Faculty of Architecture, Delft University of Technology, the Netherlands
}

\begin{abstract}
Sustainable architecture is complex. Many aspects, differently important to many stakeholders, are to be optimized. BIM should be used for this. Building Information Modellingis a collaborative process where all stakeholders integrate and optimize their information in a digital 3D model. Sometimes it is called Green BIM. But what exactly is that? Is the International Standard Organization IFC standard useful for this? And is it compatible with new developments in parametric design? Advantages and disadvantages of BIM are listed. Full parametric design is needed because it keeps the design flexible and open for changes until the end of the design process. However it is not compatible with IFC; only object parametric design is. A possible way out of this paradox could be the use of scripts that only create objects if they are not already in the BIM database and otherwise only adapt their properties. An example of parametric sustainable architectural design explains the mentioned issues.
\end{abstract}

Key words: Sustainable architecture, BIM, collaborative design, parametric design, IFC.

\section{Introduction}

Sustainable architecture is architecture that meets the needs of the present without compromising the ability of future generations to meet their own needs (adapted from Ref. [1]). One of those needs is energy for heating, cooling, lighting and equipment of buildings. Estimations show that buildings use $20-40 \%$ of the energy in Europe [2].

During the energy crises in the seventies of last century people became aware of the necessity to protect the environment and to find alternatives for fossil fuel. The book "Small is beautiful" had a big influence [3]. Function integration is still an important issue. Passive solar energy became popular, insulation of outer walls in buildings was improved and double glazed windows became the standard. There were small scale experiments to use rainwater and reuse grey water in households and compost toilets. Green roofs were re-introduced (they existed already in the stone age of course). PV panels appeared on buildings, high

Corresponding author: Ir. J. C. (Hans) Hubers, PhD, associate professor, research fields: architecture. E-mail: J.C.Hubers@tudelft.nl. efficiency boilers were installed, heat pumps and heat exchange equipment were introduced and recently rest heat from industrial plants is used in buildings nearby.

The built environment is our habitat. This word is used in Ecology to address the circumstances that make species flourish or not. Our habitat should be built with all stakeholders in mind. Municipalities could play an active role in this. They should not only approve or ask for changes in the plans, but actively interfere from the start with the design of the habitat of its citizens. Municipalities could demand for design teams with delegates representing all stake holders (including the building professionals). Such multi-disciplinary design teams can develop designs that optimally fulfil the needs and demands of all concerned.

In 1984 the author designed a sustainable office building (Fig. 1). It had a floating foundation, because of the risk of flooding and also to take profit both in summer and winter of the constant ground temperature of $10^{\circ} \mathrm{C}$. The roof construction would be made of round wood with Ethylene Tetra Fluoro Ethylene (ETFE) cushions, and has been realized several times since then. It had collection and treatment of rainwater, heat storage in salt, fish culture and a vegetable garden. The 

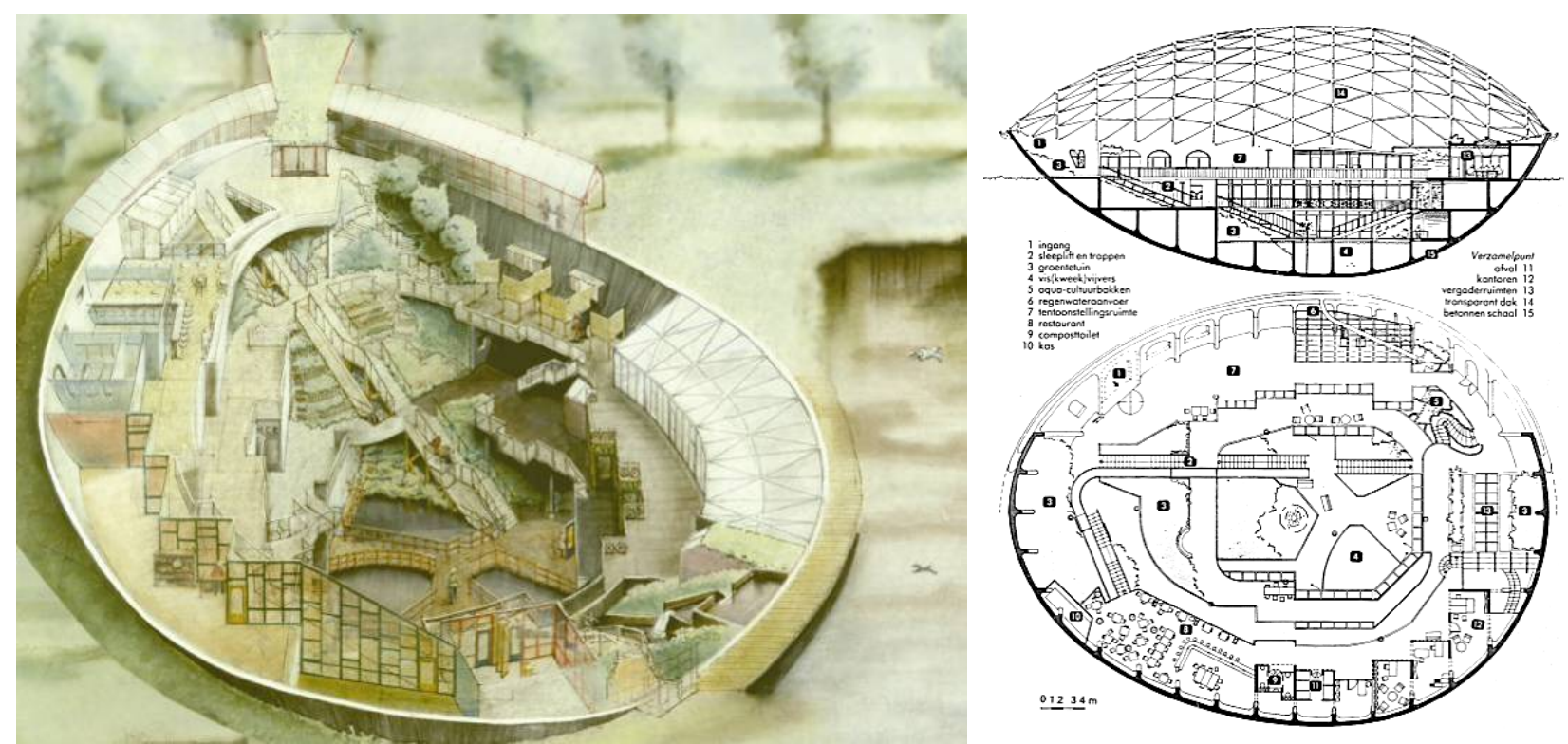

Fig. 1 Ecological office building "The Egg” [4].

feasibility study for this innovative office for the multidisciplinary centres of Delft University of Technology took 2 years. And finally it turned out that there was a negative return of investment, mainly caused by the expensive foundation. In order to speed up and to improve this kind of evaluations, multidisciplinary ICT projects were initiated.

Also around 1985 the Biosphere 2 was realised in the U.S. as a closed ecological system.Fifteen years later the Eden project was realised in England. Governments started to fund research into sustainable architecture end of the last century. Demonstration projects were funded and alternatives were stimulated with grants. The report of MIT to the Club of Rome in 1972 about the limits to growth had a big impact. People became aware of the endlessness of fossil fuel and other resources [5]. The Brundtland report in 1987 introduced the concept of sustainability. Later the triple P was added: People, Planet and Profit. Prof. Duijvestein, one of the founding fathers of sustainability at Delft University of Technology listed in detail the criteria for buildings under every P [6].

Feminias [7] gives a nice overview and analysis of demonstration projects in Sweden and The Netherlands. She concludes that though important real-world data as reference are very important, there is a lack of incentives and interest for learning; deficiencies in the production of reliable and useful information; and a lack of institutions for information dissemination.

Reuse of existing resources with as less degradation as possible (cradle to cradle) is important [8].

But it was not until vice-president $\mathrm{Al}$ Gore went over the world in 2006 showing the spectacular movie: "An Inconvenient Truth", that people became aware of global warming, the ozone hole, widespread land degradation and declining biodiversity. Standards were developed to express how well buildings perform energetically. The United States Green Building Council (USGBC) was founded in 1993. The LEED standards begin in 2000. There are many other standards like BREEAM (NL, UK), Itaca (IT) etc. Every country has its own regulations and standards. The work of JónKristinsson should be mentioned, especially his design for the Floriade 2012 [9]. Of course the IPCC reports are important references.

\section{Sustainable Building Design}

The biggest challenge stays with existing buildings, because it represents $20-40 \%$ of the energy use and $\mathrm{CO}_{2}$ emission and because it is more difficult to reduce 
this in existing buildings than to avoid it in new ones. Special attention should be paid to lighting and air-conditioning. When buildings get insulated lighting becomes relatively more important. And because of airtightness the indoor air quality becomes an issue and buildings don't lose heat during nights that easily.

Recently the author developed together with greenhouse, sustainability and other specialists a proposal for synergetic greenhouses on existing flat roofs in the cities. It is called SynSerre (Fig. 2).
One of the proposed eco-innovations in this project is the combination of multilayered ETFE (Fig. 3) cushions with reflecting patterns on the film that concentrate the spectrum of sun light which is not useful for plants ( 50\%) to PV disks mounted on space frames of round wood. Through in- and deflating the right chambers in the cushions the system becomes interactive.

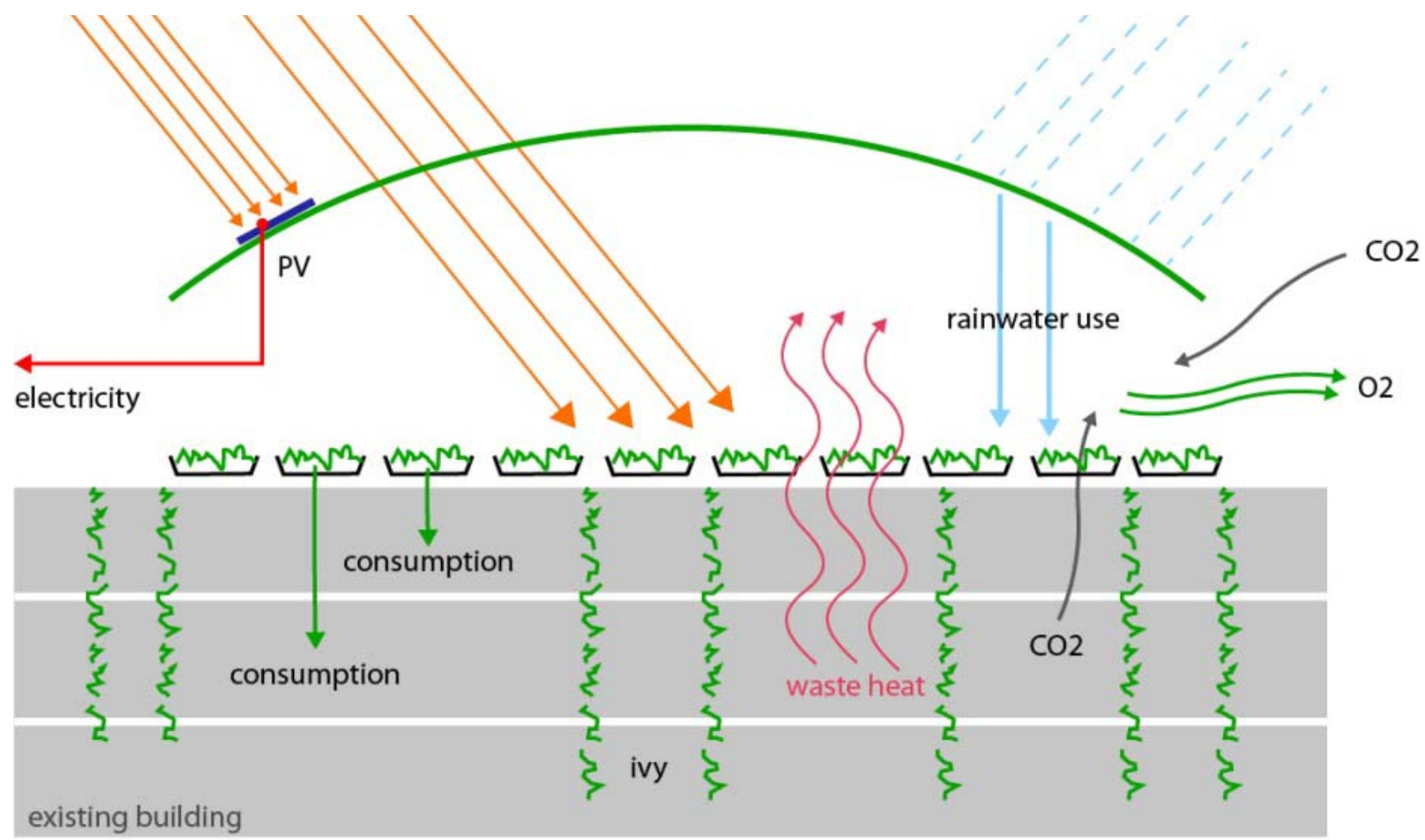

Fig. 2 Schematic representation of the SynSerre project.
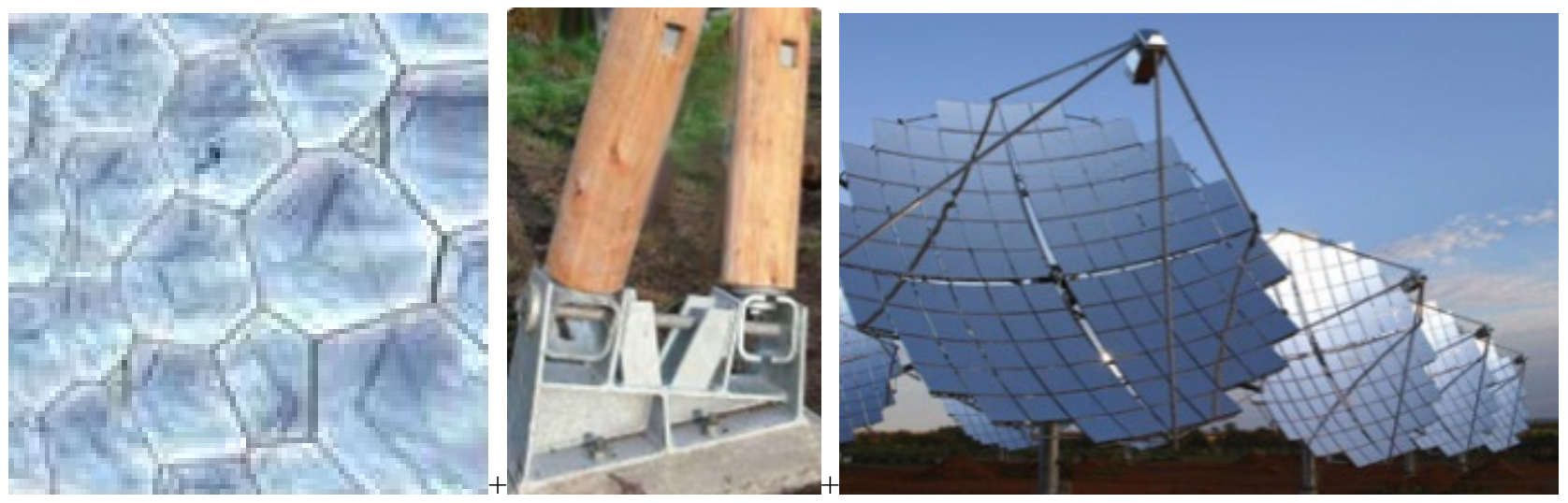

Fig. 3 ETFE cushions + Tentech round wood connection + PV concentration. 
But it could well turn out that SynSerres in Northern countries need a different solution than in Southern.If for instance $75 \%$ of direct sunlight is used for PV this will reduce the needed cooling capacity by 4 .

Traditional professional greenhouses in colder climates use much fossil fuel to be heated in winter. In the Netherlands, world leader in greenhouse development, with about 4500 greenhouse farmers and 86 million $\mathrm{m}^{2}$ of greenhouse culture [10], this sector took 4\% of the total energy use in 2008 [11]. Recently agreements have been made to bring this to zero in 2020. This means that greenhouses should not use more energy than they can produce. Several concepts have been developed and some are tested. Of course energy use is not the only criterion to be considered. The greenhouse farmers and the banks will only invest in innovations if there is a return of investment within seven years. This means that the production of vegetables, fruits, plants, flowers (the income) and the selling of energy must be balanced with the depreciation of the investment and other costs. A high knowledge of the production factors for the different crops is therefore necessary.

A SynSerre is not just a traditional greenhouse superposed on the roof of an existing building. That wouldn't be competitive with normal greenhouses. The innovation is the combination of all the points listed below.This project proposes solutions for the following problems.

(1) Depletion of fossil fuel. SynSerres supply energy and insulate existing buildings.

(2) Flooding in the world's delta areas due to climate change endanger the food supply of the growing cities. SynSerres bring food production into the cities on high and dry places.

(3) Many existing buildings in European cities with flat roofs from the sixties and seventies need renovation. Well designed and styled SynSerres are beautiful and synergetic alternatives for traditional renovation.
(4) Many of those buildings are in problematic neighbourhoods. SynSerres create jobs and offer social activities.

(5) There is a lack of space for extending greenhouses in the green areas around cities [12]. The roofs and facades of existing buildings offer considerable space for SynSerres.

(6) Cities run out of space and the value of buildings in the target areas is decreasing. There is added value through double land use.

(7) Low quality of food in supermarkets. Neighbours profit from fresh herbs, vegetables, flowers, plants and control the quality.

(8) Global warming due to $\mathrm{CO}_{2}$ and particulates. Plants convert $\mathrm{CO}_{2}$ in $\mathrm{O}_{2}$ and plant material. Particulates stick to ivy on the facades which are linked to the SynSerre.

(9) High cost for maintenance of green areas in the cities and, e.g., ivy on the facades. The greenhouse farmer maintains the green on and around the building.

(10) Overflow of sewage system during rain fall. Rainwater is collected, stored and used to grow plants.

(11) Little awareness of sustainability. SynSerre attracts attention and has an educational function.

(12) Transport causes much pollution and accidents. Less transport because of local production and trade.

Because existing buildings vary enormously, the SynSerre concept is adaptable. Parametric design software will be used and dimensions expressed in variables. The number of modules and their dimensions are matched with the existing buildings. The SynSerre will be offered as a parametric product through websites as www.conceptueelbouwen.nl. as part of an innovative turn towards an offer based building market. Clients (i.e., greenhouse farmers) buy the product in about the same way as a customisable car. The designteam receives the command, adapts the design in some days and prepares the building permit request. The consortium offers SynSerre in principle as a Design \& Build contract and shares the profit. 
The idea of SynSerre is obviously inspired by the design of Fig. 1, but combined with other ideas. In 1992 ONL, one of the partners in the project, participated in a study where greenhouses were planned on top of housing [13].

However this project was not aimed atexisting buildings and it was more an urban design. Grau [14] proposed to integrate greenhouses on the roofs of Barcelona, however also not on existing buildings and not developed as a realistic product.SynSerre partners from the leading greenhouse research centre in Europe, the Wageningen University and Research centre in the Netherlands, showed the advances of energy producing greenhouses like the Elkas and the Fresnel greenhouse [15]. This together with the ideas of Urgenda [16] and the initiative of Rotterdam [17] to turn existing flat roofs into green roofs led to the idea of this project. The Elkas (Fig. 4) produces $15-18 \mathrm{KWh} / \mathrm{m}^{2}$ year at the curved side of the roof by reflecting and concentrating the Near Infrared Radiation of the sun to an adaptable line of PV cells.

The SynSerre project will develop innovative business models where energy production, plant production and sales, environmental maintenance, educational and social activities are integrated with innovative synergetic solutions like new photovoltaic technologies. Small scale SynSerres could be exploited by restaurants or shops, while larger ones by professional greenhouse farmers. The focus will be on the latter. Two greenhouse farmers are participant in the project.

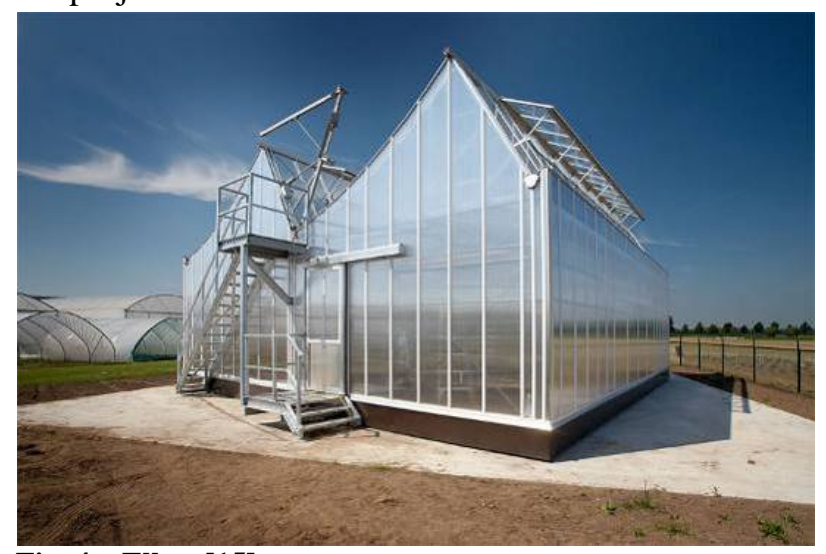

Another eco-innovation will be the integration with climate control of the existing building; e.g., convert $\mathrm{CO}_{2}$ rich exhaust air into $\mathrm{O}_{2}$ and plant growth. The examples mentioned in 1.2 will be used as starting point. There is an urgent need for feasibility studies of this concept. Two real scale test models of $100 \mathrm{~m}^{2}$ will be built and monitored; one in Delft and one in Rome. For monitoring we will use wireless Arduino based systems as can be found at http://sense.almende.com.

Now is the time to develop synergetic greenhouses on existing buildings, because the above mentioned problems are getting quickly more important and most of the suitable buildings from the sixties and seventies in the European cities need refurbishing and renovation.

Besides fossil energy use, $\mathrm{CO}_{2}$ emission and the problems mentioned before, there are other criteria that a sustainable building should answer. The author made the list in Table 1 and used it during a test case of collaborative design [18]. The list was meant to be completed by the design team. It turned out that the multidisciplinary design team only focused on a few criteria and didn't take the time to add other criteria or to evaluate all of them. Also other research shows that weighted criteria evaluation is not reliable [19]. But maybe it is better to have a badly used list of criteria, than no list at all. It at least helps efficiently focussing the discussion on the main subjects that team members don't agree about (standard deviation inTable 1).

A multidisciplinary design team needs more than a list of criteria. It needs to have good ideas! Developing ideas and evaluating them with criteria are the two main sub processes of design [18, 19]. Knowledge sharing and management is important. We plan to use Wikis for this. Wikis are websites that everybody that is authorized can easily edit. Well known is Wikipedia. Creativity is needed to turn experience and knowledge into ideas. Different techniques can be used. The use of different representations and different media is one of them [20, 21]. The work of Edward de Bono shows several methods like Random Word Stimulation,

Fig. 4 Elkas [15]. 
Analogy thinking, Brain storming etc. [22]. The Environmental Maximisation Method of Duijvestein is interesting though a bit laborious [23]. It consists of drawing the design only from the point of view of one function, e.g., water, green, sun or wind power, traffic, housing, parking etc. and later integrating the plans. Recent developments in ICT make it possible to share all this information in 3D digital models. We call this Green BIM.

Table 1 Criteria for sustainable buildings.

\begin{tabular}{|c|c|c|c|c|c|c|c|c|}
\hline \multirow{6}{*}{$\begin{array}{l}\text { Relation with } \\
\text { environment }\end{array}$} & & & & $\begin{array}{l}\text { Evaluator } 1 \\
246810\end{array}$ & & Evaluator 2 & & $\begin{array}{l}\text { Standard } \\
\text { deviation } \\
246810\end{array}$ \\
\hline & & wind hinder & 6 & 1 & 3 & $\square$ & 2 & $\square$ \\
\hline & 2 & \begin{tabular}{|l|} 
sun light \\
\end{tabular} & 5 & $\square$ & 5 & $\square$ & & J \\
\hline & & urban infrastructure & 10 & 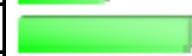 & 5 & $\square$ & 4 & $\square$ \\
\hline & 4 & waste & 4 & $\square$ & 10 & 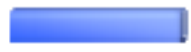 & 4 & $\square$ \\
\hline & 5 & \begin{tabular}{|l} 
view \\
\end{tabular} & 8 & 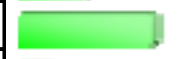 & 3 & $\square$ & 4 & $\square$ \\
\hline \multirow[t]{3}{*}{ Adaptability } & 6 & flexibility & 2 & 7 & 9 & $\square$ & 5 & $\square$ \\
\hline & 7 & expandability & 2 & $\square$ & 9 & $\square$ & 5 & $\square$ \\
\hline & 8 & handicapped & 5 & $\square$ & 5 & $\square$ & & I \\
\hline Spatial & 9 & routing & 8 & $\square$ & 7 & $\square$ & 1 & 0 \\
\hline \multirow[t]{3}{*}{ organization } & 10 & viewing lines & 9 & $\longrightarrow$ & 9 & $\square$ & $\rightarrow$ & I \\
\hline & 11 & functional relations & 9 & $\square$ & 9 & $\square$ & & | \\
\hline & 12 & privacy & 3 & $\square$ & 8 & $\square$ & 4 & $\square$ \\
\hline \multirow[t]{4}{*}{ Safety } & 13 & fire & 8 & $\square$ & 8 & 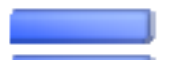 & & I \\
\hline & 14 & burglary & 8 & $\square$ & 8 & $\square$ & 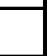 & I \\
\hline & 15 & flood & 5 & $\square$ & 5 & $\square$ & -1 & I \\
\hline & 16 & traffic & 5 & $\square$ & 8 & $\square$ & 2 & D \\
\hline \multirow[t]{6}{*}{ Experience } & 17 & recognizablity & 9 & $\square$ & 9 & $\square$ & & I \\
\hline & 18 & proportions & 9 & 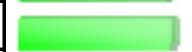 & 9 & $\square$ & T & I \\
\hline & 19 & rhythm & 9 & 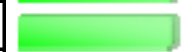 & 9 & 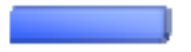 & 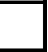 & ! \\
\hline & 20 & \begin{tabular}{|l} 
acoustics \\
\end{tabular} & 5 & $\square$ & 5 & $\square$ & 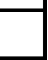 & j \\
\hline & 21 & comfort & 7 & $\square$ & 3 & $\square$ & 3 & 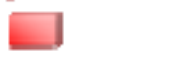 \\
\hline & 22 & contrast & 9 & 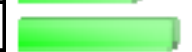 & 9 & $\square$ & 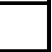 & ! \\
\hline \multirow[t]{3}{*}{ Materials } & 23 & \begin{tabular}{|l|} 
colour \\
\end{tabular} & 9 & 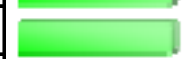 & 3 & $\square$ & 4 & $\square$ \\
\hline & 24 & \begin{tabular}{|l|} 
texture \\
\end{tabular} & 9 & 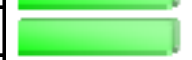 & 3 & $\square$ & 4 & $\square$ \\
\hline & 25 & sustainability & 5 & $\square$ & 5 & $\square$ & & ! \\
\hline \multirow[t]{3}{*}{ Construction } & 26 & \begin{tabular}{|l} 
safety \\
\end{tabular} & 5 & $\square$ & 5 & $\square$ & 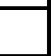 & I \\
\hline & 27 & comfort & 5 & $\square$ & 5 & $\square$ & 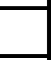 & J \\
\hline & 28 & \begin{tabular}{|l} 
speed \\
\end{tabular} & 4 & $\square$ & 2 & $\square$ & 1 & a \\
\hline \multirow[t]{6}{*}{ Energy use } & 29 & insulation & 5 & $\square$ & 5 & $\square$ & $\rightarrow$ & J \\
\hline & 30 & outer surface & 8 & 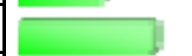 & 8 & 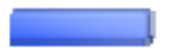 & & | \\
\hline & 31 & wind tightness & 5 & $\square$ & 5 & $\square$ & & i \\
\hline & 32 & \begin{tabular}{|l|} 
ventilation \\
\end{tabular} & 5 & $\square$ & 5 & $\square$ & & I \\
\hline & 33 & sun light & 3 & $\square$ & 3 & $\square$ & & i \\
\hline & 34 & lighting & 8 & $\square$ & 8 & $\square$ & & | \\
\hline Cost & & initial, maintenance, demolition & 9 & $\square$ & 5 & $\square$ & 3 & $\square$ \\
\hline
\end{tabular}




\section{BIM}

BIM is mainly used in the meaning of Building Information Modelling, the process of making a Building Information Model. Collaborative design is one of the main aspects of BIM [18, 24, 25]. We define it as follows. Collaborative architectural design is multidisciplinary simultaneous design from the very start of a project. It is also called co-design or concurrent engineering.

The pressure to use IFC based BIM is growing. IFC is an ISO standard. A good introduction to IFC-based BIM is to be found in Khemlani [26]. Autodesk adopted it a.o. in Autodesk Revit. Other major CAD developers in the AEC industry support it too. The Dutch part of the buildingSMART association, which develops IFC, states in her newsletter that the directions of Governmental Services of U.S., Denmark, Finland, Norway and the Netherlands signed an agreement for adopting IFC based BIM for all major government projects [27]. Contractors for a long time are working on this and recently the Dutch Conceptual Building network starts working in this direction too [28]. The conceptual building approach converts the demand market into an offer market. Providers of concepts no longer wait for a client to define a demand, but develop complete adaptable solutions that clients can order. It is more or less like in the car business: lean production and mass customization.

The simulation of buildings is a vital benefit. VR systems like CAVEs and Head Mounted Displays are used for that. Delft University of Technology developed a lab called protoSPACE which uses these techniques [29]. Eastman et al. report 10 case studies of realized buildings.

The 16 reported benefits are summarised in Table 2 with the number of projects that had these benefits. Benefit 9 "Earlier collaboration of multiple design disciplines" is in the Construction execution/coordination phase and thus not collaborative design as we define it. Not one project had all those benefits. Besides benefits of BIM there
Table 2 Advantages of BIM (Adapted from Ref. [24]).

\begin{tabular}{|l|l|}
\hline \multicolumn{2}{|l|}{ Feasibility study } \\
\hline 1 & Support for project scoping and cost estimation (2) \\
\hline Concept design \\
\hline 2 & Scenario planning (2) \\
\hline 3 & Early and accurate visualizations (3) \\
\hline 4 & Optimize energy efficiency and sustainability (1) \\
\hline Integrated design/construction \\
\hline 5 & Automatic maintenance of consistency in design (8) \\
\hline 6 & Enhanced building performance and quality (5) \\
\hline 7 & Checks against design intent (3) \\
\hline 8 & Accurate and consistent drawings sets (8) \\
\hline Construction execution/coordination \\
\hline 9 & Earlier collaboration of multiple design disciplines (6) \\
\hline 10 & Synchronize design and construction planning (5) \\
\hline 11 & Discover errors before construction planning (5) \\
\hline 12 & $\begin{array}{l}\text { Drive fabrication and greater use of prefabricated } \\
\text { components (5) }\end{array}$ \\
\hline 13 & Support lean construction techniques (2) \\
\hline 14 & Coordinate/synchronize procurement (4) \\
\hline Facility operation \\
\hline 15 & Lifecycle benefits regarding operation costs (1) \\
\hline 16 & Lifecycle benefits regarding maintenance (1) \\
\hline
\end{tabular}

are also drawbacks of course. It is obvious that BIM asks for much knowledge about 3D, 4D, 5D, nD CAD knowledge (4D is planning, $5 \mathrm{D}$ is cost, $\mathrm{nD}$ is management etc.). Then there are the difficulties of author/ownership and liability of the BIM. Contracts like Design Build and Guaranteed Maximum Price have enormous impact on the concerned professional practices [25].

Recently parametric design software is used. Two main groups of parametric design software can be distinguished: process parametric (Fig. 5) or object parametric (Fig. 7). The problem is that only object parametric design software is compatible with IFC [30].

To explain this, a short description of an IFC file is needed. It is a plain textfile with numbered lines representing objects in the design with standard names, like IF Ccolumnand between brackets their attributes, e.g., what type of column (in this case a PIPE102STD). Attributes canalso be references to other objects, and thus \#numbers (Fig. 6). 


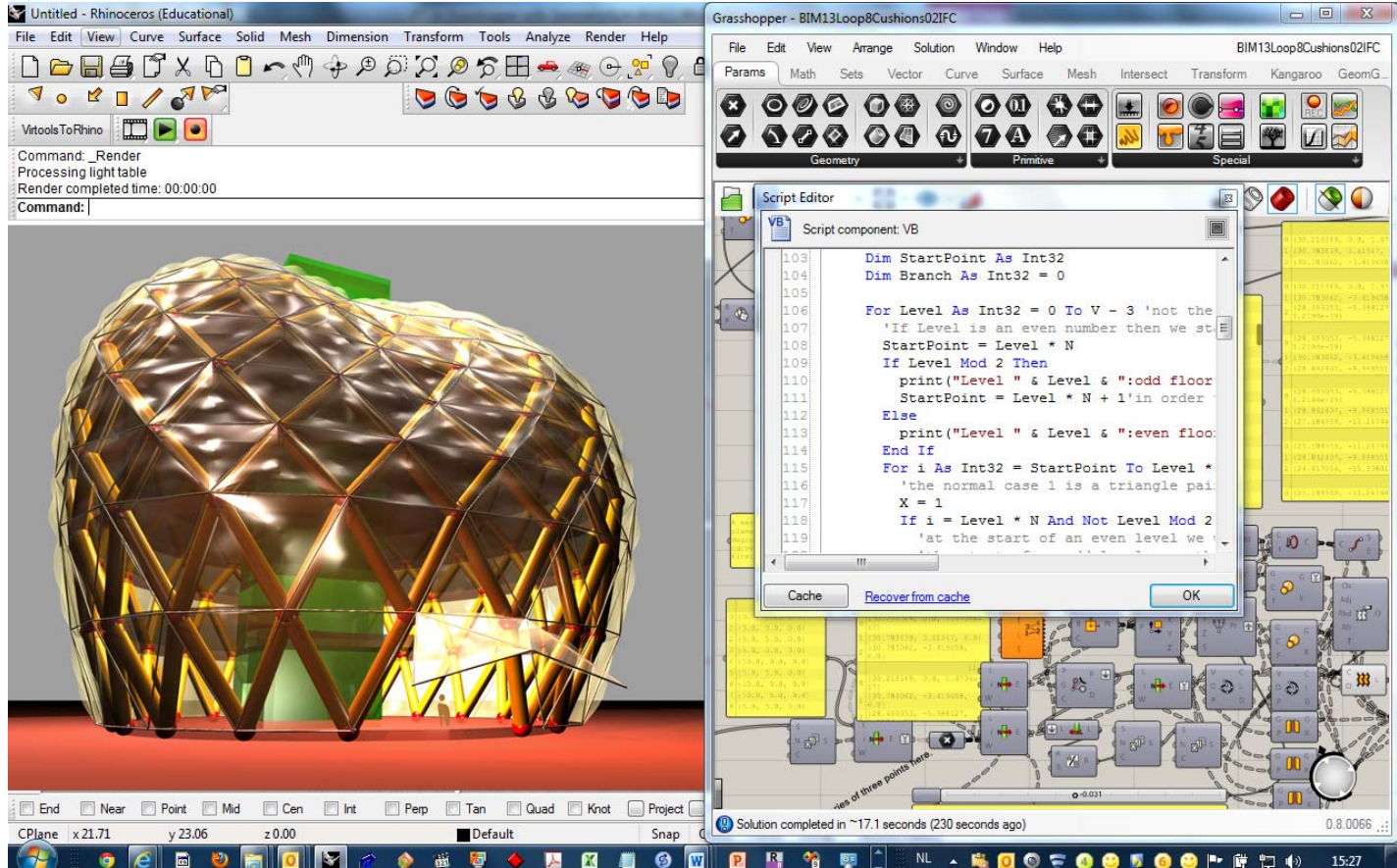

Fig. 5 Process parametric design with scripting in Rhino.

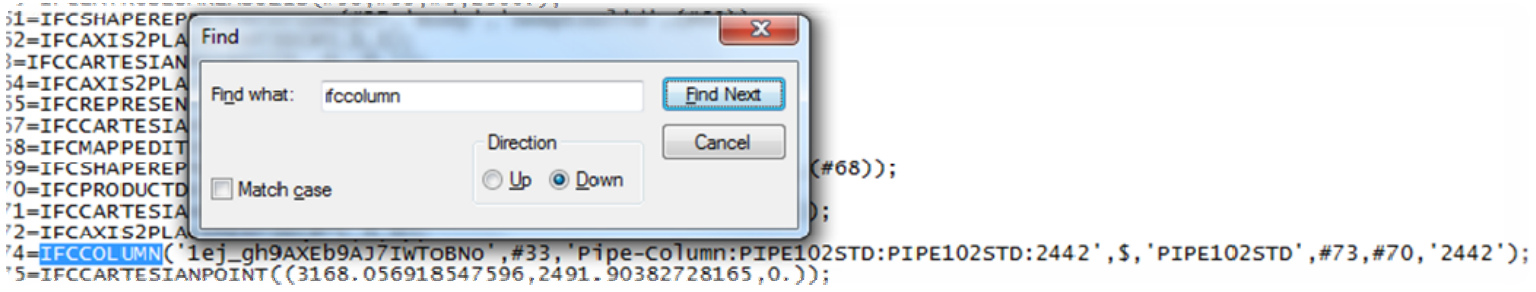

Fig. 6 Part of an IFC file.

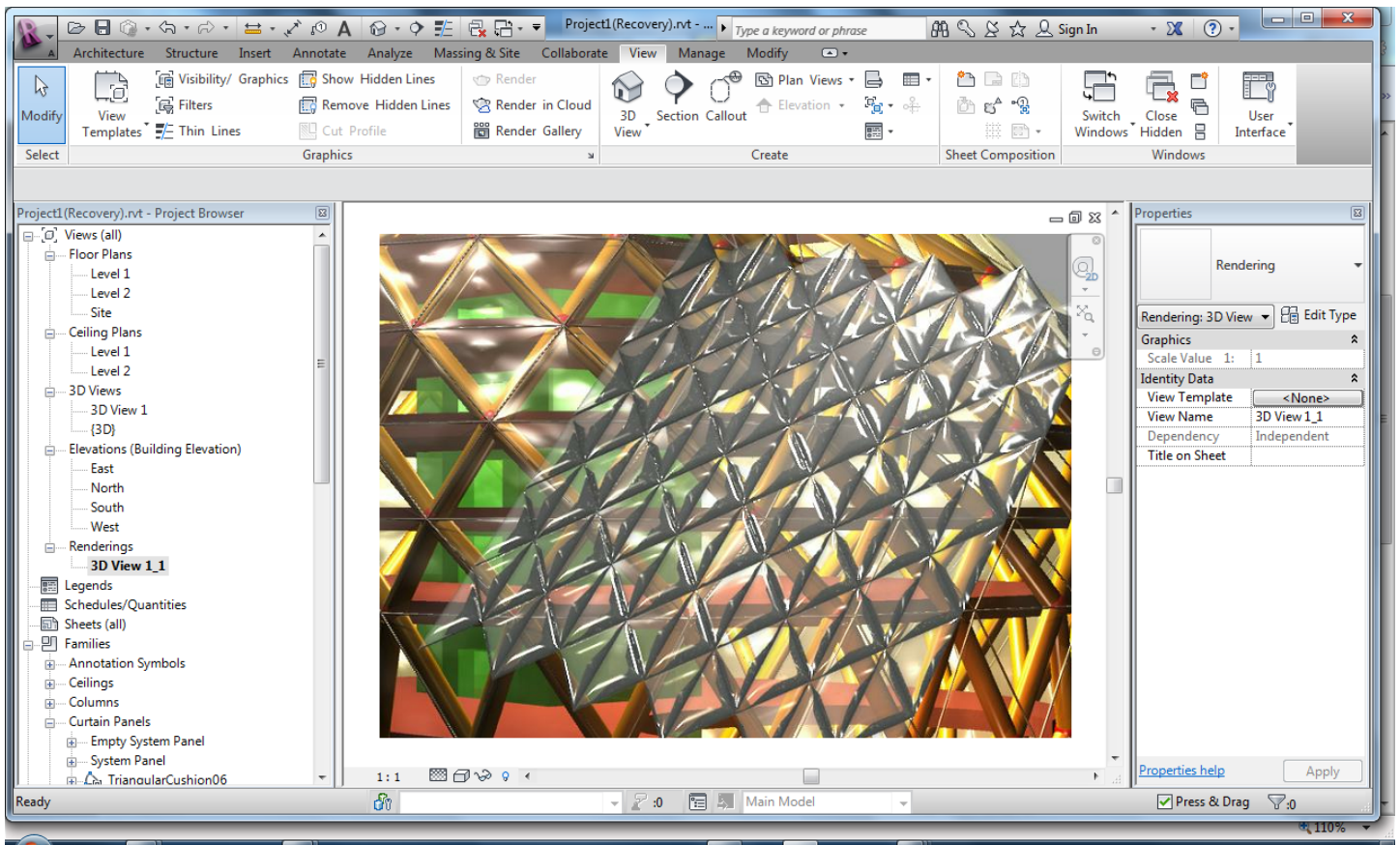

Fig. 7 Recreation of object parametric ETFE cushions in Revit Architecture. 
Object parametric software, like Revit, defines these objects and attributes in libraries (in Revit called families). Objects and attributes can be parameterised there. E.g., the thickness of the pipe will be 1/50 of its diameter. In the model parameterisation is also possible. E.g., the diameter of the column could be made $1 / 10$ of its length and its length equal to the storey height etc. Thus when the story height is changed, nothing has to be redrawn, everything updates automatically. This is very important, because the design team can easily change the design with the last information or adapt it to other circumstances. Even more flexible is the design with process parametric software like Rhino/Grasshopper. Here the objects are generated by code; nothing is drawn. Every time a peace of code (the grey rectangles, called components) or its parameters is changed, the whole script is updated and everything that is turned on is regenerated. There is a special component where the code can be written by the user in C\# or VBA (the window in the window in the window in Fig. 5). Process parametric software is very powerful, but not so handy if the objects have to be exchanged through IFC with other software. It is possible with the GeometryGym plug-in to exchange IFC files, but importing creates static objects - not generating script components. Thus making the script useless after the first exchange in most cases. If, e.g., all the diameters of the columns have to change, it is not so hard to find in the script where to change this parameter, but if this should only be the case near the entrance, where some columns have been removed it is very difficult to find which cycle through the generation of the columns have to get an exception through an If-Then-Else statement.

Also if objects don't exist in the standard libraries, like is the case with triangular ETFE cushions, also used in the SynSerre project, first one has to find a way to define these objects in an exchangeable way. At the moment of writing lofts through parameterised co-planar curves seems to work.

\section{Conclusion}

Sustainable architecture has many criteria to fulfil of many stakeholders. A promising idea is to develop synergetic greenhouses on flat roofs of existing buildings. Research is needed to find ways to use both IFC based BIM and full parametric design software. Only then multidisciplinary teams can work efficiently together on sustainable architectural designs. A solution might be the use of scripts that only create objects if they are not already in the BIM database and otherwise only adapt their properties.

This article is based on a paper by the author for the conference Management and Innovation for a Sustainable Built Environment ISBN: 9789052693958, 20-23 June 2011, Amsterdam, The Netherlands.

\section{References}

[1] WCED, Our common future: Report of the World Commission on Environment and Development, 1987, available online at: http://www.worldinbalance.net/ $\neg$ intagreements/1987-brundtland.php.

[2] IEA, Energy efficiency requirements in building codes: Energy efficiency policies for new buildings, IEA Publications, 2008.

[3] E. F. Schumacher, Small is Beautiful, Blond \& Briggs: London, 1973.

[4] J. C. Hubers, Eindelijk een gebouw dat met alles rekening houdt: “Het Ei”, in: Bouw, februari’86, 1986, pp. 10-14.

[5] D. H. Meadows, D. L. Meadows and J. Randers, The limits to growth: A report for the Club of Rome's project on the predicament of mankind, New York: New American Library, 1972.

[6] SenterNovem, available online at: http://www.senternovem.nl/mmfiles/Position\%20paper\% 20-Duurzame\%20ᄀBedrijfsvoering\%20Rijk_tcm24-3389 88.pdf, 2009.

[7] P. Femenias, Demonstration projects for sustainable building, $\mathrm{PhD}$ Thesis, Chalmers University of Technology, Göteborg, available online at: http://www.habiterautrement.org/01_tendances/contributi ons-01/Projects-for-Sustainable-Building-thesis_femenias -1.pdf, 2004.

[8] W. McDonough and M. Braungart, Cradle to Cradle, North Point Press, New York, 2002.

[9] J. Kristinsson, available online at: http://www.kristinssonarchitecten.nl/projecten/images/90 06/ᄀ9006-1.jpg. 
[10] CBS1, Netherlands statistics, Glastuinbouw, available online at: http://statline.cbs.nl/StatWeb/publication $/$ ?DM=SLNL\&PA=80782NED\&D1=0,295,338-339,360, 363-364\&D2=0-5,7-10,12-13,15,17,19,21-25,28,30-32,3 4-35,41-42,44\&D3=a\&HDR=T,G2\&STB=G1\&VW=T, 2011.

[11] CBS2, Netherlands statistics, Energieverbruik, available online at: http://statline.cbs.nl/StatWeb/publication $/$ ?DM=SLNL\&PA=80382ned \&D1=1,4,6,9\&D2=a\&D3=( l-2)-l\&VW=T, 2011.

[12] VROM, available online at: https://kennispleinmooinederland.vrom.nl/projecten/type n\#type10, 2010.

[13] A. Bhalotra, K. A. Oosterhuis, A. J. Alblas, J. C. Alblas and Witteveen, City fruitful, in: G. W. de Vries (Ed.), 010 Publishers Rotterdam, 1992.

[14] L. Grau, Sustainable district in Barcelona, in: $H$. Wamelink, M. Prins and R. Geraedts (Eds.), Changing Roles: New Roles, New Challenges, TU Delft Faculty of Architecture Real Estate \& Housing, Delft, 2009.

[15] WUR, available online at: http://www.glastuinbouw.wur.nl/UK/expertise/design/, 2010.

[16] Urgenda, available online at: http://www.urgenda.nl/visie/, 2010.

[17] Rotterdam, available online at: http://www.rotterdamclimateinitiative.nl/en/100_climate_ proof/-rotterdam_climate_proof/results, 2010.

[18] J. C. Hubers, Collaborative architectural design in virtual reality, $\mathrm{PhD}$ Thesis, Faculty of Architecture of Delft University of Technology, The Netherlands, available online at: http://www.bk.tudelft.nl/users /hubers/internet/ᄀDissertatieHansHubers(3).pdf, 2008.

[19] B. R. Lawson, How Designers Think, Architectural Press/Elsevier, Oxford, 2006.
[20] M. C. Stellingwerff, Virtual context, investigating the characteristics and opportunitiesof digital visualisation media for situated approaches to architectural design in an urban environment, Ph.D. Thesis, Delft University of Technology, The Netherlands, 2005.

[21] D. A. Schön, The Reflective Practitioner: How Professionals Think in Action, Basic Book Inc. U.S.A., 1983.

[22] E. de. Bono, Lateral Thinking: A Textbook of Creativity, Harmondsworth Penguin, 1980.

[23] C. A. J. Duijvestein, The environmental maximisation method, in: T. M. D. Jong and D. J. M. v. d. Voordt, Ways to Study and Research Urban, Architectural And Technical Design, Delft University Press, 2002.

[24] C. Eastman, P. Teichholz, R. Sacks and K. Liston, BIM Handbook, Wiley, Hoboken, New Jersey, U.S.A., 2008.

[25] B. Hardin, BIM and construction management.Sybex, Indianapolis, Indiana, U.S.A., 2009.

[26] L. Khemlani, The IFC Building Model: A Look Under the Hood, in: AEC-bytes, available online at: http://www.aecbytes.com/feature/2004/IFCmodel.html.

[27] BS, Newsletter April 2009 nr1, available online at: http://bw-dssv07.bwk.tue.nl/ $\neg$ files/-newsletters/nieuwsbri ef-buildingsmart-22-04-2009.pdf.

[28] CB, available online at: http://www.conceptueelbouwen.nl/?mod=cbouwen\&id=1 $7 \& \mathrm{act}=\mathrm{cb} \_\neg$ english.

[29] J. C. Hubers, Collaborative design in Protospace 3.0, in: H. Wamelink, M. Prins and R. Geraedts (Eds.), Changing Roles; New Roles, New Challenges, TU Delft Faculty of Architecture Real Estate \& Housing, Delft, 2009.

[30] J. C. Hubers, Collaborative parametric BIM, in: A. Bennadji, B. Sidawi and R. Reffat (Eds.), Proceedings of the 5th ASCAAD Conference 2010, Robert Gordon University, Scotland, 2010. 